\title{
PRAKTIKUM MEKANISME LISTRIK DALAM PEMBELAJARAN FISIKA SMP OLEH MAHASISWA S1 UIN SULTAN SYARIF KASIM
}

\author{
Dandi Inplant Guspandi ${ }^{*}$, Rian Vebrianto \\ ${ }^{1}$ Program Studi Tadris IPA, UIN Sultan Syarif Kasim Riau \\ ${ }^{2}$ Program Pasca Sarjana PGMI, UIN Sultan Syarif Kasim Riau \\ *Email: inplantguspandi@gmail.com
}

DOI: http://dx.doi.org/10.29303/jpft.v5i2.1263

\begin{abstract}
The purpose of making this article is to find out the deepening of the material about electrical circuits, the workings of electrical circuits, as between modules with the purpose of the practicum that has been done. This type of research is used by using literature studies and direct practices carried out in the Science Education laboratory room. The subjects used by them are students majoring in semester 2 Science Education University of Sultan Syarif Kasim Riau. The results of the research are the number of students who do not understand about the electricity practices that discuss modules because of the large number of vocabulary that is not understood by students. For this reason, it is necessary to increase the practicum in the future, especially in the module, using language that is easily understood by students and students, and also with a guide who understands what he teaches practicum compilation.
\end{abstract}

Keywords: Physics; Electrical; Practice

\section{PENDAHULUAN}

Pada topik besaran pokok dan turunan penguasaan konsep fisika peserta didik, dengan bantuan multimedia interaktif meningkat secara maksimal yaitu $100 \%$. Didalam materi IPA Terpadu untuk jenjang SMP/MTs, terdapat pembelajaran fisika yaitu berkenaan dengan listrik statis dan dinamis. Tidak ada yang mencolok dari materi listrik ini, karena untuk jenjang SMP yang dipelajari mengenai listrik adalah dasar-dasar dari listrik.

Rangkaian listrik merupakan konsep dasar dalam suatu pembelajaran mengenai listrik. Rangkaian listrik dibagi menjadi 3, yaitu raingkaian listrik seri, rangkian listrik paralel, dan rangkaian listrik gabungan (seri dan paralel).

Mengenai praktikum rangkaian seri dan paralel dalam pembelajaran fisika tingkat SMP, ini termasuk materi yang cukup mudah untuk dipelajari, karena yang dibahas pada praktikum ini adalah bagaimana susunan rangkaian listrik seri, paralel dan campuran, mencari nilai hambatan di masing-masing resistor pada suatu rangkaian listrik, dan tegangan serta kuat arus listrik dalam suatu rangkaian.

Banyak kesulitan mahasiswa dalam melakukan praktikum ini, untuk itu penulis mengambil langkah untuk meneliti dan menganalisis apa saja yang perlu diperbaiki baik daam modul praktikum maupun proses pelaksanaan praktikum.

\section{METODE PENELITIAN}

Metode penelitian dalam jurnal ini menggunakan subyek mahasiswa S1 Jurusan Tadis IPA Semester 2. Sumber metode penelitian ini menerapkan kepada:

1. Studi kasus yang melibatkan 27 orang mahasiswa.

2. Studi literatur yang melibatkan beberapa sumber bacaan perihal rangkaian listrik seri dan paralel dan gabungan. Referensi mengambil dari modul praktikum Fisika Dasar mengenai Rangkaian Seri dan Paralel, beberapa hasil laporan mahasiswa dan beberapa buku dan jurnal berkaitan dengan penerapan listrik dalam pembelajaran.

3. Inventaris alat dan bahan praktikum yang berkaitan mengenai rangkaian listrik 
sesuai dengan yang terdapat dalam modul riset mahasiswa.

\section{HASIL DAN PEMBAHASAN}

Hasil dari inventaris dapat dilihat pada tabel 1.1. Melalui inventaris tersebut, dapat dirangkai arus listrik seri dan paralel bahk.an gabungan, sesuai dengan modul yang telah disusun sebelumnya.

Tabel 1. Daftar alat-alat inventaris praktikum

\begin{tabular}{ccc}
\hline alat & Spesifikasi & jumlah \\
\hline Catu daya & $9 \mathrm{~V}$ & 1 \\
\hline Multitester & $\begin{array}{c}\text { Multimeter } \\
(\Omega, i, V)\end{array}$ & 1 \\
\hline $\begin{array}{c}\text { Hambatan/ } \\
\text { resistor } \\
\text { warna }\end{array}$ & $\begin{array}{c}47 \times 10^{2} \Omega, \\
12 \times 10^{2} \Omega, \\
22 \times 10^{2} \Omega\end{array}$ & $\begin{array}{c}\text { Masing-masing } \\
\text { nilai } \\
\text { hambatanny 1 } \\
\text { buah }\end{array}$ \\
\hline $\begin{array}{c}\text { Kabel } \\
\text { penghubung }\end{array}$ & - & $\begin{array}{c}2 \text { buah, panjang } \\
\text { diukur sesuai } \\
\text { kebutuhan,tidak } \\
\text { perlu panjang }\end{array}$ \\
\hline $\begin{array}{c}\text { Project } \\
\text { board / } \\
\text { bread board }\end{array}$ & - & 1 buah \\
\hline
\end{tabular}

Berdasarkan kebutuhan karakteristik data, maka dapat menghitung berapa kuat arus, tegangan dan hamabatan yang dihasilkan dalam suatu rangkaian listrik. Data-data yang telah disebutkan sesuai dengan tujuan dari praktikum yang ditunjukkan oleh modul yang telah disusun sebelumnya.

Untuk melihat nilai $V$ dengan mengukur menggunakan multitester. Dengan begitu, kita dapat melihat berapa nilai kuat arus dan hambatan yang dihasilkan dalam suatu rangkaian listrik.

Untuk mencari nilai hambatan yang dihasilkan dalam suatu rangkaian seri, paralel aupun rangkaian gabungan, kita dapat menentukannya dengan menggunakan perhitungan manual, maupun dengan menggunakan alat multitester yang telah disediakan sebelumnya.

Didalam modul telah disebutkan cara kerja dalam rangkaian yaitu:

A. Rangkaian Seri

1. 3 buah resistor dengan nilai tahanan $1,2 \mathrm{k} \Omega, 2,2 \mathrm{k} \Omega$, dan $4,7 \mathrm{k} \Omega$ (nilai dapat diketahui dengan membaca kode warna) dan selanjutnya diukur dengan menggunakan multimeter. Kemudian rangkai dengan rangkaian seri.

2. Hubungkan power supply ke sumber listrik dengan tegangan 9 volt untuk arus DC.

3. Hubungkan kutub positif power supply (masukan) dengan kutub positif resistor dan hubungkan kutub negatif resistor dengan kutub negatif power supply (keluaran)

4. Ukur nilai arus dan tegangan pada setiap resistor dengan menggunakan multimeter.

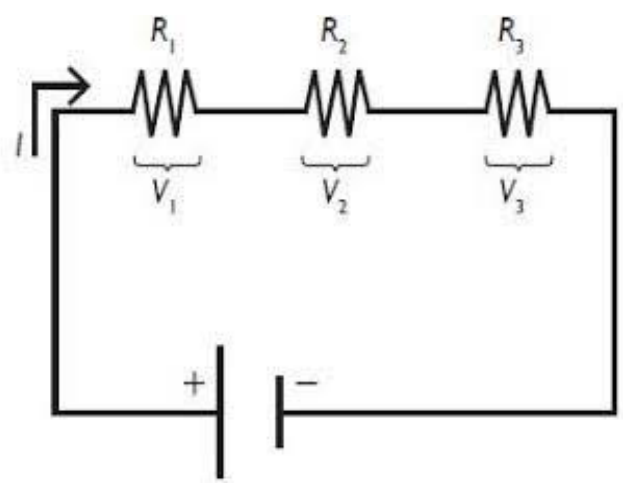

Gambar 1. Rangkaian listrik seri

B. Rangkaian Paralel

1. 3 buah resistor dengan nilai tahanan $1,2 \mathrm{k} \Omega, 2,2 \mathrm{k} \Omega$, dan 4,7 $\mathrm{k} \Omega$ (nilai dapat diketahui dengan membaca kode warna) dan selanjutnya diukur dengan menggunakan multimeter. Kemudian rangkai dengan rangkaian paralel. 
2. Hubungkan power supply ke sumber listrik dengan tegangan 9 volt untuk arus DC.

3. Hubungkan kutub positif power supply (masukan) dengan kutub positif resistor pertama $\left(R_{l}\right)$ dan hubungkan kutub negati resistor ketiga $\left(R_{3}\right)$ dengan kutub negatif power supply (keluaran).

4. Ukur nilai arus dan tegangan pada setiap resistor dengan meggunakan multimeter.

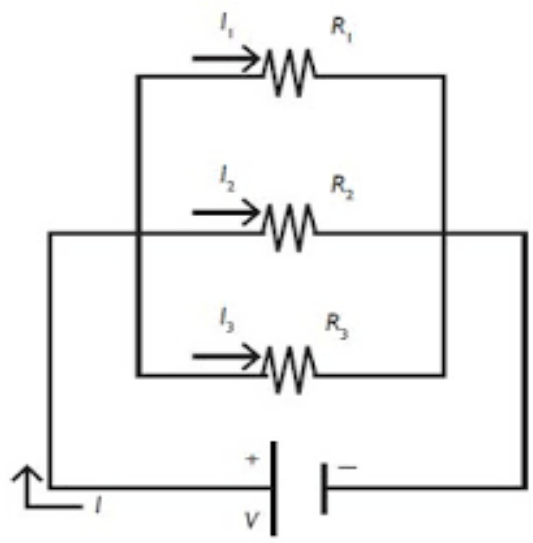

Gambar 2. Rangkaian listrik paralel

C. Rangkaian Gabungan

1. 3 buah resistor dengan nilai tahanan $1,2 \mathrm{k} \Omega, 2,2 \mathrm{k} \Omega$, dan 4,7 $\mathrm{k} \Omega$ (nilai dapat diketahui dengan membaca kode warna) dan selanjutnya diukur dengan menggunakan multimeter. Kemudian rangkai dengan rangkaian seri.

2. Hubungkan power supply ke sumber listrik dengan tegangan 9 volt untuk arus DC.

3. Hubungkan kutub positif power supply (masukan) dengan kutub positif resistor pertama $\left(R_{l}\right)$ dan hubungkan kutub negatif resistor dua atau tiga $\left(R_{2} / R_{3}\right)$ dengan kutub negatif power supply (keluaran).

4. Ukur nilai arus dan tegangan pada setiap resistor dengan meggunakan multimeter.

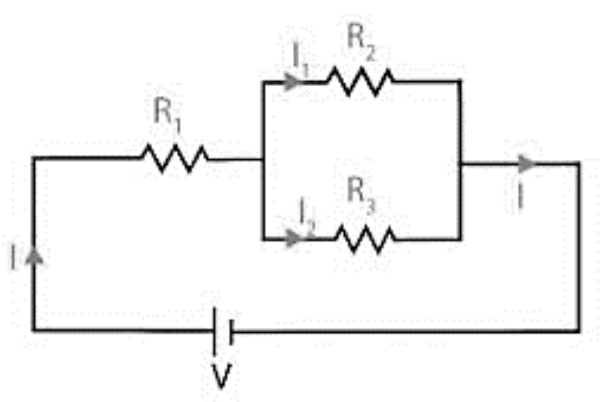

Gambar 3. Rangkaian listrik campuran

Di dalam praktikum yang dilakukan oleh mahasiswa ini adalah untuk mencari nilai tegangan listrik, kuat arus listrik, dan hambatan listrik dengan persamaan berikut:

1. Rangkaian listrik seri: $\mathrm{R}_{1}+\mathrm{R}_{2}+\mathrm{R}_{3}+$ $\mathrm{Rn}$.

Rangkaian listrik paralel: $\frac{1}{R 1}+\frac{1}{R 2}+\frac{1}{R 3}+\frac{1}{R n}+\ldots \ldots$

2. Kuat arus listrik: $I=\frac{q}{t}$, t dalam sekon.

3. Untuk mencari tegangan, dapat dihitung dengan Hukum Ohm dengan rumus: $V=I \times R$

Diatas adalah cara kerja dari rangkaian praktikum yang dilaksanakan oleh mahasiswa Jurusan Tadris IPA semester 2 UIN Sultan Syarif Kasim.

Akan tetapi, banyak mahasiswa yang tidak mengerti dengan cara kerja yang disediakan di modul praktikum. Hasil survey yang telah dilakukan bahwa, sebanyak 55\% dari jumlah mahasiswa yang tidak mengerti dengan praktikum listrik ini. Hal ini karena banyaknya kosakata bahasa yang tidak dimengerti oleh mahasiswa itu sendiri, dan beberapa dari merekea juga tidak tahu penggunaan multitester dengan baik, dan juga kurangnya panduan dari dosen maupun asisten dosen mengenai jalannya praktikum. Hal ini diperlunya peningkatan poses praktikum dilaboratorium dengan baik, tidak hanya praktikum, tetapi juga ada pembelajaran sebelum praktikum, agar mahasiswa dapat memahami materi dengan baik. 
Materi listrik merupakan salah satu materi penting dan kompleks dalam fisika. mahasiswa pada berbagai tingkat pendidikan mengalami miskonsepsi dan kesulitan dalam memahami konsep dasar listrik, bahkan pembimbing praktikum yang merupakan mahasiswa tingkat atas juga kesulitan dalam memahami listrik, terutama penggunaan alat praktikum.

Praktik menggunakan media simulasi merupakan solusi yang mungkin untuk membuat pengetahuan abstrak menjadi konkret di kelas. Kegiatan menggunakan simulasi penting karena bisa merangsang minat siswa dalam pembelajaran kelas, membantu memvisualisasikan pengetahuan, dan meminimalkan kesulitan yang biasanya ditemukan dalam pembelajaran. Penguatan pembelajaran melalui buku ajar, media, dengan metode pembelajaran yang tepat akan mendapatkan kualitas pemahaman yang lebih tinggi. Belajar disertai sejumlah aktivitas maupun praktikum secara langsung menghasilkan retensi hingga 90\%, semakin banyak kesempatan yang diberikan, siswa belajar semakin banyak. Isi dari buku harus memberikan siswa kesempatan belajar mandiri, melimpahkan banyak waktu untuk aktivitas siswa, sehingga secara otomatis siswa belajar, sehingga siswa bisa menguasai materi dengan lebih baik .

Hasil observasi selama ujicoba modul praktikum tampak bahwa mahasiswa dalam mengerjakan tugas pendahuluan dan pertanyaan sangat tergantung pada mahasiswa yang dianggap terpandai di kelompok atau di kelas terkait. Diskusi antar mahasiswa dalam kelompok dan literasi referensi terkait tidak terlalu tampak. Mayoritas mahasiswa hanya mengandalkan modul praktikum yang dibagikan peneliti sebagai sumber bacaan. Kemandirian mahasiswa dalam mengerjakan laporan masih sangat kurang sehingga mayoritas isi modul praktikum yang dikumpulkan tampak sangat homogen.

Hasil penelitian ini diperkuat dengan pendapat Trianto (2009) menjelaskan bahwa pembelajara kontekstual merupakan konsep belajar yang membantu guru dengan mengaitkan materi yang disampaikan dan diajarkan dengan situasi keadaan nyata siswa, dan membantu mendorong siswa membuat keterkaitan antara pengetahuan yang dimilikinya dengan penerapan kehidupan sehari-hari.

\section{PENUTUP}

Kesimpulan yang dapat diambil dari pembahasan yang telah disampaikan adalah: bahwa rangkaian listrik merupakan konsep dasar dalam suatu pembelajaran mengenai listrik. Rangkaian listrik dibagi menjadi 3, yaitu raingkaian listrik seri, rangkian listrik paralel, dan rangkaian listrik gabungan (seri dan paralel). Dalam penelitian, kami menggunakan modul praktikum yang telah disediakan oleh dosen pengampuh

Akan tetapi, dalam praktiknya, banyak mahasiswa yang tidak mengerti dengan cara kerja yang disediakan di modul praktikum, hal ini karena banyaknya kosakata bahasa yang tidak dimengerti oleh mahasiswa itu sendiri.

\section{REFERENSI}

Alós, P \& Lago, R., 2012. Ebook, An Innovative Tool Towards the Teaching-Learning Process. Huelva: Department of Psychology and Education. University of Huelva (Spain).

Hidayatullah, M., Wiryokusumo, I., Waluji, D.A . 2019. Remidiasi Miskonsepsi Siswa Pada Materi Listrik Dinamis Menggunakan Ebook Interaktif. Jurnal Pendidikan Fisika dan Teknologi. 5(1): 30-39

Gunawan, Harjono, A., Sutrio. 2015. Multimedia Interaktif Dalam 
Pembelajaran Konsep Listrik Bagi Calon Guru. Jurnal Pendidikan Fisika dan Teknologi. Vol 1(1): 9-14

Tim Erlangga Fokus UN. 2017. Erlangga Fokus UN 2018 IPA. Jakarta: Penerbit Erlangga

Ramdhani, Mohamad. 2008. Rangkaian Listrik. Jakarta: Penerbit Erlangga

Murdaka Eka Jati, Bambang, Tri Kuntoro Priyambodo. 2010. Fisika Dasar listrik-Magnet, Optika, Fisika Modern. Yogyakarta: Penerbit Andi.

Andriani, Riza, Niki Dian Permana Putra. Modul Panduan Praktikum Fisika Dasar Terintegrasi Nilai-Nilai Keislaman Dalam Al-Qur'an. Pekanbaru

Trianto. 2009. Mendesain Model Pembelajaran Inovatif-Progresif. Jakarta : Kencana.

Wijayanti, Winda, Nengah Maharta, Wayan Suana. 2017. Pengembangan Perangkat Blended Learning berbasis Learning Management System Pada Materi Listrik Dinamis. Jurnal Ilmiah Pendidikan Fisika Al-Biruni 06 (1) 112

Junliani, Rita, Fitri Meliana. 2014. Pengaruh Strategu Genius Learning Terhadap Hasil Belajar Siswa Pada Materi Fisika Tiopi Listrik Dinamis Kelas IX SMP Swasta Raksana Medan. Jurnal Pendidikan Fisika. 3(1).

Zaus, Mahesi Agni, Rizky Ema Wulansari, Syaiful Islami, Doni Pernanda. 2018. Perancangan Media Pembelajaran Listrik Statis Dan Dinamis Berbasis Android. Jurnal of Information Technology and Computer Science. 1(1): 1-7

Yulianci, S., Gunawan, \& Doyan, A. 2017. Model Inkuiri Terbimbing Berbantuan Multimedia Interaktif untuk Meningkatkan Penguasaan Konsep Fisika Peserta Didik. Jurnal Pendidikan Fisika dan Teknologi. 3 (2): 146-154. 